Article

\title{
Assessment of the Health Effects of Heavy Metals Pollution of Agricultural Soils in the Iron Ore Mining Area of the Northern Piedmont of Mount Wutai, Shanxi Province, China
}

\author{
Dandan Wang ${ }^{1}$, Qinghai $\mathrm{Xu}^{1, *}$, Qingrong Zheng ${ }^{2, *}$ and Liwei $\mathrm{Wu}^{2}$ \\ 1 College of Resources and Environment, Hebei Normal University, Shijiazhuang 050016, China; \\ 13730122028@163.com \\ 2 Department of Geography, Xinzhou Teachers University, Xinzhou 034000, China; xztcwuliwei@163.com \\ * Correspondence: xuqinghai@mail.hebtu.edu.cn (Q.X.); 13803441882@163.com (Q.Z.)
}

Received: 30 November 2019; Accepted: 21 February 2020; Published: 3 March 2020

\begin{abstract}
We have measured the concentrations of toxic elements ( $\mathrm{Cd}, \mathrm{Pb}, \mathrm{As}$, and $\mathrm{Hg}$ ) in 29 samples from agricultural soils in an iron ore mining area in the northern piedmont of Mount Wutai in Shanxi Province, China. The aim was to evaluate the potential health risks to local inhabitants based on the health risk assessment model derived from the United States Environmental Protection Agency (USEPA). The results show that the concentrations of the four heavy metals exceed their background values, especially in the case of $\mathrm{Hg}$. The pollution level of the four heavy metals can be ordered as follows: $\mathrm{Hg}>\mathrm{Cd}>\mathrm{Pb}>\mathrm{As}$. The spatial distribution of the concentrations of the four heavy metals was uneven: pollution levels were lowest in the basin of the E River, and centered on the E River there was an increasing trend towards the Yukou River in the west and the Yangyan River in the east. In terms of the degree of pollution, this trend can be summarized as: Qingyang River $>$ Yangyan River $>$ Yukou River $>$ E River. The main form of ingestion of the metals was via mouth and nose, and the risk to children is higher than for adults. Iron ore mining was the main cause of the increased concentrations of As and $\mathrm{Cd}$, which represent a cancer risk for humans.
\end{abstract}

Keywords: northern piedmont area of Mount Wutai; iron mining; agricultural soils; contamination status; health risk assessment

\section{Introduction}

Heavy metals pollution is a major environmental problem and poses a significant threat to human health [1-3]. Large amounts of various heavy metals are released during mining, smelting, and commercial activities. Heavy metals accumulate in the soil, water, and atmosphere, and thus they constitute a health risk. Their accumulation in agricultural soils clearly presents a major health risk $[4,5]$. Certain heavy metals are essential for biological systems, including those of humans, as structural and catalytic components of proteins and enzymes. However, the excessive accumulation of heavy metals in the environment constitutes a health risk for humans. Notably, $\mathrm{Cd}, \mathrm{Pb}, \mathrm{As}$, and $\mathrm{Hg}$ are endocrine-disrupting chemicals [6]. For instance, excessive levels of cadmium in the human body cause high blood pressure and cardiovascular and cerebrovascular diseases $[7,8]$. Lead is the most pernicious heavy metal and can damage human brain cells, affecting the intellectual development of children and causing dementia in the elderly $[9,10]$. Arsenic can affect skin pigmentation and lead to abnormal keratinization [11,12]. Mercury directly accumulates in the liver when it is ingested by humans, causing damage to the brain and nervous system and affecting vision [13]. Therefore, it is 
necessary to evaluate the health risk of heavy metals to humans, a topic that is of major societal concern and has attracted much research attention.

Yang et al. [14] evaluated the degree of heavy metals pollution and the resulting health risk in the Huayuan mining area of Hunan Province, and reported that the concentrations of $\mathrm{Pb}, \mathrm{Zn}$, and $\mathrm{Cd}$ exceeded the safe background levels determined by the State Environmental Protection Administration of Standard for risk control of soil pollution in agricultural land of soil environmental quality (GB 15618-1995) [15]. It was suggested that $\mathrm{Pb}$ and $\mathrm{Cd}$ posed a substantial health risk to residents via the consumption of vegetables from local agricultural lands. Chen et al. [16] assessed the health risks of heavy metals pollution in the Longxi lead-zinc mining area of Fujian Province. Fang et al. [17] used a single factor index and the Nemerow integrated pollution index to analyze the pollution levels of heavy metals in agricultural soil in Lin'an City in Hangzhou, and found that the degree of $\mathrm{Pb}$ pollution was moderate, while for $\mathrm{Cd}, \mathrm{Cu}$, and $\mathrm{Zn}$ it was slight, and that 160 samples were contaminated to a certain extent.

The northern piedmont of Mount Wutai in Shanxi Province has important iron ore reserves that are mined, and in addition there are scattered gold mines. The local soil environment has been seriously damaged as a result of large-scale mining activities, and human health has been affected. However, little attention has been paid to determining the possible levels of heavy metals pollution in agricultural soils in the region and the resulting health risks. Consequently, we collected 29 samples of agricultural soil from different locations in the area with the aim of analyzing the spatial distribution of the concentrations of heavy metals $(\mathrm{Cd}, \mathrm{Pb}, \mathrm{As}$, and $\mathrm{Hg})$. In order to determine the risk to human health we analyzed the data using determinations of the single factor pollution index (SFPI) and the Nemerow integrated pollution index, and we also applied the health risk assessment model developed by the United States Environmental Protection Agency (USEPA) [18-21]. It was hoped that the results would provide a scientific basis for the implementation of a regulatory policy by the government.

\section{Materials and Methods}

\subsection{Study Site and Sampling}

The study area is the northern piedmont of Mount Wutai, which is in the northeast part of Shanxi Province in China $\left(113^{\circ} 10^{\prime}\right.$ to $114^{\circ} 00^{\prime} \mathrm{E}$ and $39^{\circ} 00^{\prime}$ to $\left.39^{\circ} 15^{\prime} \mathrm{N}\right)$. The upper reaches of the Hutuo River lie to the north; the Yedoufeng peak of Beitai Mountain lies to the south; and the towns of Yuli and Shentangbao are situated to the west and east, respectively (Figure 1). The landscape of the area is dominated by mountains with elevations up to $\sim 3000 \mathrm{~m}$, and therefore the soil types exhibit a distinct vertical zonation. The following soil types occur in the region, with decreasing altitude: subalpine meadow soil, montane meadow soil, mountain grassland meadow soil, brown soil-brown loam soil, leached cinnamon soil, calcareous cinnamon soil, and cinnamon soil. The geological structure of the study area is complex and the region has undergone multiple tectonic movements, which has resulted in mineralization, with metamorphic iron ores being abundant and widely distributed [22,23]. A large number of industrial and mining enterprises have developed in the area that have resulted in the accumulation of pollutants in the soil via wind transport and surface runoff. 


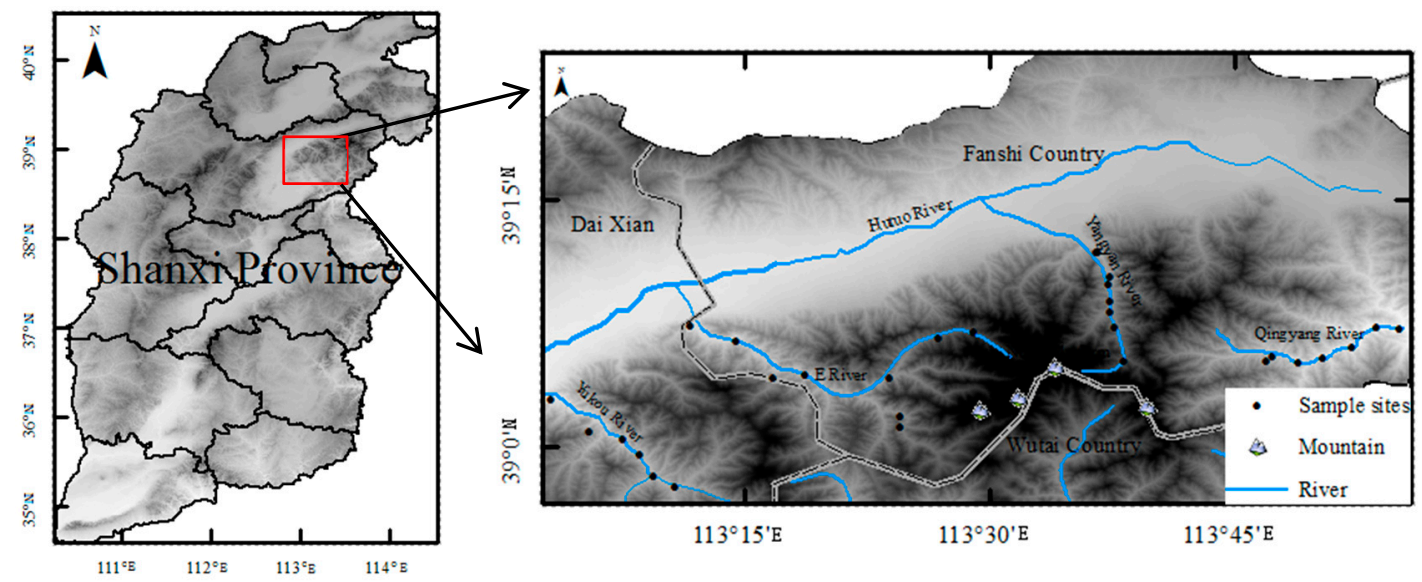

Figure 1. Location of the study area in Shanxi Province (left) and location of soil sampling (right).

\subsection{Sample Collection and Measurement of Heavy Metal Concentrations}

Twenty-nine sampling sites were selected in different agricultural areas in the Mount Wutai area and samples were collected in June 2017. The sites were in agricultural fields located close to the iron ore mining plants near the Yukou River, E River, Yangyan River, and Qingyang River. Samples were taken using the 'Plum Blossom arrangement', which is suitable for small plots, flat terrain, and urban areas with a uniform degree of pollution. In each sampling point, five subsamples of approximately $500 \mathrm{~g}$ were collected and mixed to obtain composite soil samples. The top $0-20 \mathrm{~cm}$ of the soil layer was sampled. At the same time, the location and environmental characteristics of each sampling site were recorded in detail. In the laboratory, the soil samples were spread over a polyethylene sheet, air-dried at room temperature for two weeks, ground to a fine powder in a grinding rod swing mill, sieved through a $0.15-\mathrm{mm}$ polyethylene sieve and homogenized to remove stones and plant roots. All the soil was kept in scaled plastic bags until analysis.

All samples received pretreatment and preparation of a standard solution and were measured in the Taiyuan Testing Center of the Ministry of Land and Resources, Shanxi Province according to the National Soil Quality standard (GB15618-1995) [15] and the Modern Analysis methods of soil elements (1992) [24]. All reagents used were of analytical grade. Water used was secondary distilled water. As, $\mathrm{Hg}, \mathrm{Pb}$, and Cd (National Network of Standard Material Centers, $100 \mu \mathrm{g} \cdot \mathrm{mL}^{-1}$ ) were multielemental standard solutions. Soil samples were digested using a mixture of $\mathrm{HNO}_{3}(15 \mathrm{~mL})-\mathrm{HCI}$ $(10 \mathrm{~mL})-\mathrm{HF}(10 \mathrm{~mL})-\mathrm{HCIO}_{4}(5 \mathrm{~mL})$ for the determination of the total concentrations of $\mathrm{Cd}$ and $\mathrm{Pb}$, while the As and $\mathrm{Hg}$ concentrations were determined after aqua regia (3:1 $\mathrm{HCI}(15 \mathrm{~mL})$ and $\mathrm{HNO}_{3}$ $(5 \mathrm{~mL})$ ). The concentrations of $\mathrm{Cd}, \mathrm{Pb}$, As, and $\mathrm{Hg}$ were measured using XSERIES 2 ICP-MS (Thermo Fisher Scientific, USA). The monitoring range of ICP-MS is 3-250 amu, and the detection limit is ppt level [25]. Standard curves were plotted using the standard solution concentrations of $\mathrm{Cd}, \mathrm{Pb}, \mathrm{As}$, and $\mathrm{Hg}$ measured by ICP-MS with correlation coefficients of $0.9999,0.9998,0.999,0.9999$, respectively. These met the requirements of inductively coupled plasma mass spectrometry for the determination of heavy metal elements in soils and sediments (HJ 803-2016) (correlation coefficients greater than 0.999). The detection limits were $0.003,0.001,0.006,0.004 \mu \mathrm{g} \cdot \mathrm{L}^{-1}$, respectively, meeting the detection requirements for metals. The indicators in their accuracy were within the standard substances (GSS-25, GSS-12) scope of uncertainty. 


\subsection{Determination of Heavy Metal Pollution Indices}

\subsubsection{Single Factor Pollution Index}

The single factor pollution index (SFPI) is an effective method for evaluating the pollution level of heavy metals; however, it does not reflect overall pollution levels in a region [26]. The SFPI is calculated using the following equation:

$$
\mathrm{Pi}=\frac{\mathrm{C}_{\mathrm{i}}}{\mathrm{S}_{\mathrm{i}}}
$$

where $\mathrm{Pi}$ is the pollution index of element $\mathrm{i}, \mathrm{C}_{\mathrm{i}}$ is the measured data for metal $\mathrm{i}$ and $\mathrm{S}_{\mathrm{i}}$ is the soil background value. The heavy metals content of the soil in the Mount Wutai area measured in 1986 was used as the background value of the study (no iron ore mining installations were present before 1986). The values of $\mathrm{Cd}, \mathrm{Pb}$, As, and $\mathrm{Hg}$ were $0.104,15.67,8.90$ and $0.07 \mathrm{mg} \cdot \mathrm{kg}^{-1}$, respectively [27].

\subsubsection{Nemerow Integrated Pollution Index}

The Nemerow integrated pollution index (NIPI) provides a comprehensive measure of the overall pollution level of a study area [28] and enables comparisons to be made between different regions. The index is calculated using the following equation [29]:

$$
\mathrm{P}_{\mathrm{N}}=\sqrt[2]{\left(\frac{(\mathrm{Pi})_{\mathrm{ave}^{2}+(\mathrm{Pi})_{\max }{ }^{2}}^{2}}{2}\right)}
$$

where $\mathrm{P}_{\mathrm{N}}$ is the soil pollution index, and $(\mathrm{Pi})_{\text {ave }}$ and $(\mathrm{Pi})_{\max }$ are the average and maximum value $\mathrm{s}$ of the pollution element $i$ within a specific area, respectively. The classification criteria for assessment of the soil heavy metals pollution index are shown in Table 1 [30].

Table 1. Classification criteria for heavy metals pollution in soil.

\begin{tabular}{ccccc}
\hline Class & $\begin{array}{c}\text { Pollution Index of } \\
\text { Element I }\end{array}$ & $\begin{array}{c}\text { Pollution Index of } \\
\text { Soil }\end{array}$ & Pollution Class & Pollution Level \\
\hline 1 & $\mathrm{Pi} \leq 0.7$ & $\mathrm{P}_{\mathrm{N}} \leq 0.7$ & Secure & Clean \\
2 & $0.7<\mathrm{Pi} \leq 1$ & $0.7<\mathrm{P}_{\mathrm{N}} \leq 1$ & Alert & Unpolluted \\
3 & $1<\mathrm{Pi} \leq 2$ & $1<\mathrm{P}_{\mathrm{N}} \leq 2$ & Mild & Began to be polluted \\
4 & $2<\mathrm{Pi} \leq 3$ & $2<\mathrm{P}_{\mathrm{N}} \leq 3$ & Moderately & Moderately polluted \\
5 & $\mathrm{Pi}>3$ & $\mathrm{P}_{\mathrm{N}}>3$ & Heavy & Extremely polluted \\
\hline
\end{tabular}

\subsection{Health Risk Assessment}

Health risk assessment focuses on the possible effects of certain pollutants on human health after they reach a certain dose level, and it includes cancer risk and noncarcinogenic risk. According to the classification systems of the USEPA Integrated Risk Information System (IRIS) and the International Agency for Research on Cancer (IARC), Cd and As are chemical carcinogens, while $\mathrm{Pb}$ and $\mathrm{Hg}$ are noncarcinogenic chemicals [31-33].

\subsubsection{Exposure Assessment}

Heavy metals in soils are transferred to the human body mainly via ingestion, inhalation, and dermal contact by hand and mouth $[28,34,35]$. The following equations are used to calculate the level of human exposure to heavy metals based on average daily intake $\left(\mathrm{mg}^{\mathrm{k}} \mathrm{kg}^{-1} \cdot \mathrm{day}^{-1}\right) \mathrm{by} \mathrm{a}^{\mathrm{a}}$ given route:

$$
\begin{aligned}
\mathrm{ADD}_{\text {ing }} & =\frac{\mathrm{c} \cdot \operatorname{IngR} \cdot \mathrm{CF} \cdot \mathrm{EF} \cdot \mathrm{ED}}{\mathrm{BW} \cdot \mathrm{AT}} \\
\mathrm{ADD}_{\text {inh }} & =\frac{\mathrm{c} \cdot \mathrm{InhR} \cdot \mathrm{EF} \cdot \mathrm{ED}}{\mathrm{PEF} \cdot \mathrm{BW} \cdot \mathrm{AT}}
\end{aligned}
$$




$$
\begin{gathered}
\mathrm{ADD}_{\text {derm }}=\frac{\mathrm{c} \cdot \mathrm{SA} \cdot \mathrm{CF} \cdot \mathrm{SL} \cdot \mathrm{ABS} \cdot \mathrm{EF} \cdot \mathrm{ED}}{\mathrm{BW} \cdot \mathrm{AT}} \\
\mathrm{ADD}=\mathrm{ADD}_{\text {ing }}+\mathrm{ADD}_{\text {inh }}+\mathrm{ADD}_{\text {derm }}
\end{gathered}
$$

where $A D D_{\text {ing }}, \mathrm{ADD}_{\text {inh }}$, and $\mathrm{ADD}_{\text {derm }}$ are the average daily intake of heavy metals via ingestion, inhalation, and dermal contact, respectively; $\mathrm{c}$ is the concentration of metals in the soil $\left(\mathrm{mg}^{\mathrm{kg}}{ }^{-1}\right)$; IngR is the ingestion rate $\left(\mathrm{mg} \cdot \mathrm{day}^{-1}\right) ; \mathrm{CF}$ is a conversion factor $\left(\mathrm{kg} \cdot \mathrm{mg}^{-1}\right)$; $\mathrm{EF}$ is the exposure frequency $\left(\right.$ day $\left.\cdot \mathrm{yr}^{-1}\right)$; $\mathrm{ED}$ is the exposure duration (yr); BW is the body weight of the exposed individual (kg); AT is the average exposure time for noncarcinogenic effects (day); $\operatorname{InhR}$ is the inhalation rate $\left(\mathrm{m}^{3} \cdot \mathrm{day}^{-1}\right)$; PEF is the particle emission factor $\left(\mathrm{m}^{3} \cdot \mathrm{kg}^{-1}\right)$; SA is the exposed skin area $\left(\mathrm{cm}^{2}\right)$; SL is the skin adherence factor $\left(\mathrm{mg} \cdot\left(\mathrm{cm}^{2} \cdot \text { day }\right)^{-1}\right)$; and ABS is the dermal absorption factor (dimensionless). The value of each parameter is compared with the results of previous studies and with the actual conditions of Chinese residents [36,37], enabling suitable exposure parameters to be determined (Table 2).

\begin{tabular}{|c|c|c|c|}
\hline \multirow{2}{*}{ Parameter } & \multicolumn{2}{|c|}{ Value } & \multirow{2}{*}{ Data Source } \\
\hline & Adults & Children & \\
\hline Ingestion Rate (mg·day $\left.{ }^{-1}\right)$ & 100 & 200 & $\begin{array}{l}\text { United States Environmental } \\
\text { Protection Agency(USEPA) }\end{array}$ \\
\hline Inhalation Rate $\left(\mathrm{m} 3 \cdot \mathrm{day}^{-1}\right)$ & 20 & 7.65 & USEPA \\
\hline Conversion Factor $\left(\mathrm{kg} \cdot \mathrm{mg}^{-1}\right)$ & $10^{-6}$ & $10^{-6}$ & USEPA \\
\hline Exposure Frequency $\left(\right.$ day $\left.\cdot \mathrm{yr}^{-1}\right)$ & 350 & 350 & USEPA \\
\hline Exposure Duration(yr) & 24 & 6 & USEPA \\
\hline Exposed Skin Area $\left(\mathrm{cm}^{2}\right)$ & 5145 & 2670 & {$[36,37]$} \\
\hline Skin Adherence Factor $\left(\mathrm{mg} \cdot\left(\mathrm{cm}^{2} \cdot \text { day }\right)^{-1}\right)$ & 0.07 & 0.2 & USEPA \\
\hline Dermal Absorption Factor & 0.001 & 0.001 & USEPA \\
\hline Particle Emission Factor $\left(\mathrm{m}^{3} \cdot \mathrm{kg}^{-1}\right)$ & $1.36 \times 10^{9}$ & $1.36 \times 10^{9}$ & USEPA \\
\hline Body Weight of the Exposed Individual (kg) & 56.8 & 15.9 & {$[36,37]$} \\
\hline Average Exposure Time(day) & $\begin{array}{l}\mathrm{ED} \times 365^{*} \\
70 \times 365^{* *}\end{array}$ & $\begin{array}{l}\mathrm{ED} \times 365^{*} \\
70 \times 365^{* *}\end{array}$ & USEPA \\
\hline
\end{tabular}

Table 2. Definition and reference values of some parameters for health risk assessment.

Note: * noncarcinogenic absorption time; ${ }^{* *}$ carcinogenic absorption time

\subsubsection{Health Risk Characterization Assessment}

A model of carcinogenic and noncarcinogenic health risk assessment is defined as follows $[18,38,39]$ :

$$
\begin{gathered}
\mathrm{HQ}_{\mathrm{i}}=\sum_{\mathrm{j}=1}^{3} \frac{\mathrm{ADD}_{\mathrm{ij}}}{\mathrm{RfD}_{\mathrm{ij}}} \\
\mathrm{HI}=\sum_{\mathrm{i}=1}^{4} \mathrm{HQ}_{\mathrm{i}} \\
\mathrm{CR}_{\mathrm{i}}=\sum_{\mathrm{j}=1}^{3} \mathrm{ADD}_{\mathrm{ij}} \cdot \mathrm{SF}_{\mathrm{ij}} \\
\mathrm{TCR}=\sum_{\mathrm{i}=1}^{2} \mathrm{CR}_{\mathrm{i}}
\end{gathered}
$$

where $i$ is a heavy metal; $j$ represents the three pathways described above; HQ is the hazard quotient, which is typically used to characterize noncarcinogenic hazards; $\mathrm{HI}$ is the hazard index, which is used to assess the overall potential for noncarcinogenic effects posed by more than one chemical; RfD is the reference dose, which is an estimate of the maximum permissible risk to human populations through 
daily exposure $\left(\mathrm{mg} \cdot(\mathrm{kg} \cdot \mathrm{day})^{-1}\right)$; and $\mathrm{CR}$ and TCR are the carcinogenic risk and total carcinogenic risk, respectively, which are the probability that an individual will develop any type of cancer over a lifetime of exposure to carcinogenic hazards. For carcinogenic risk, the slope factor (SF) is used to directly convert the estimated daily intake of a toxin averaged over a lifetime of exposure to the incremental risk of an individual developing cancer. If the HQ or HI are less than 1, the exposed population is unlikely to experience obvious adverse health effects, while if $\mathrm{HQ}$ or $\mathrm{HI}$ are greater than one, then the value indicates the probability of adverse health effects $[18,20,40]$. These results were evaluated with reference to China's guidelines for site environmental assessment (DB11/T 656-2009) and research results from both China and elsewhere $[39,41]$ (Table 3).

Table 3. Reference doses for noncarcinogenic metals and slope factors for carcinogenic metals.

\begin{tabular}{|c|c|c|c|c|c|c|}
\hline \multirow{2}{*}{ Element } & \multicolumn{3}{|c|}{ Reference Dose/mg.(kg·day)_ ${ }^{1}$} & \multicolumn{3}{|c|}{ Slope Factor $/(\mathrm{kg} \cdot$ day $) \cdot \mathrm{mg}^{-1}$} \\
\hline & Ingestion & Inhale & Dermal & Ingestion & Inhale & Dermal \\
\hline $\mathrm{Cd}$ & $1 \times 10^{-3}$ & $1 \times 10^{-3}$ & $12.4 \times 10^{-5}$ & 6.1 & $1.8 \times 10^{-3}$ & 6.1 \\
\hline $\mathrm{Pb}$ & $3.5 \times 10^{-3}$ & $3.52 \times 10^{-3}$ & $5.25 \times 10^{-4}$ & - & - & - \\
\hline As & $3 \times 10^{-4}$ & $1.23 \times 10^{-4}$ & $3 \times 10^{-4}$ & 1.5 & $4.3 \times 10^{-3}$ & 1.5 \\
\hline $\mathrm{Hg}$ & $3 \times 10^{-4}$ & $3 \times 10^{-4}$ & $2.4 \times 10^{-5}$ & - & - & - \\
\hline
\end{tabular}

\section{Results and Analysis}

\subsection{Soil Heavy Metals Content and Spatial Distribution Characteristics}

\subsubsection{Soil Heavy Metals Content}

The measured concentrations of the four heavy metals and their background values in the agricultural soils of the piedmont area of Mount Wutai are presented in Table 4 . The soil in the study area was alkaline. The concentrations of the four heavy metals decreased in the following order: $\mathrm{Pb}>\mathrm{As}$ $>\mathrm{Hg}>\mathrm{Cd}$ (with average values of $41.18,16.05,0.97$, and $0.32 \mathrm{mg} \cdot \mathrm{kg}^{-1}$, respectively). The concentration of $\mathrm{Hg}$ was the highest relative to the background value, and it exceeded the background level by a factor 13.84; the equivalent enrichment factors for $\mathrm{Cd}, \mathrm{Pb}$ and As were 3.06, 2.63, and 1.80, respectively. The results of the application of the coefficient of variation analysis $(\mathrm{CV})$ were classified as follows: high variation, $\mathrm{CV}>0.36$; intermediate variation, $0.16<\mathrm{CV}<0.36$; low variation, $\mathrm{CV}<0.16$ [42]. For the studied agricultural soils, the values for all four elements exceeded 0.36 , with the following values: $\mathrm{Cd}, 1.10 ; \mathrm{Pb}, 0.75 ; \mathrm{As}, 1.34 ; \mathrm{Hg}, 2.47$.

Table 4. Summary statistics of the heavy metals content of agricultural soil in the northern piedmont of Mount Wutai.

\begin{tabular}{cccccc}
\hline Analyzed value & $\mathbf{C d}$ & $\mathbf{P b}$ & $\mathbf{A s}$ & $\mathbf{H g}$ & $\mathbf{p H}$ \\
\hline Average, $\mathrm{mg} \cdot \mathrm{kg}^{-1}$ & 0.32 & 41.18 & 16.05 & 0.97 & 8.03 \\
$\bullet \quad$ Range, $\mathrm{mg} \cdot \mathrm{kg}^{-1}$ & $0.088-1.804$ & $4.65-138.21$ & $1.31-108.51$ & $0.018-13.4$ & \\
$\bullet \quad \mathrm{SD}$ & 0.35 & 30.69 & 21.52 & 2.40 & \\
$\bullet$ & 1.10 & 0.75 & 1.34 & 2.47 \\
$\bullet \quad$ Ex & 3.06 & 2.63 & 1.80 & 13.84 \\
Referens multiple $^{\text {a }}$ & 0.104 & 15.67 & 8.90 & 0.070 & \\
\hline
\end{tabular}

\subsubsection{Spatial Distribution Characteristics of Heavy Metals}

The method of inverse distance weighting was used to analyze the spatial distribution characteristics of heavy metals in the agricultural soils. As shown in Figure $2, \mathrm{Cd}, \mathrm{Pb}$, and $\mathrm{As}$ had similar distributions, with low concentrations adjacent to the E River and values increasing away from the river on both sides. The Yangyan River had the highest concentrations, representing a serious 
level of heavy metal pollution. The pollution levels were lower in the upper reaches of both the Yangyan River and Qingyang River, and they increased downstream, indicating that flowing water is an important agent in the transport and dispersion of heavy metals. The wastewater from ore dressing water contributes a lot to the heavy metals in suspended matter of the river and was an important carrier for heavy metal transport. The concentrations of $\mathrm{Hg}$ increase from the middle of the study area to both sides, with the highest values located in the eastern Qingyang River area, which reflects the size and number of iron ore locations. A few samples in the middle reach of the Yukou River exhibited relatively high concentrations of $\mathrm{Hg}$, reflecting the influence of gold mining activity.
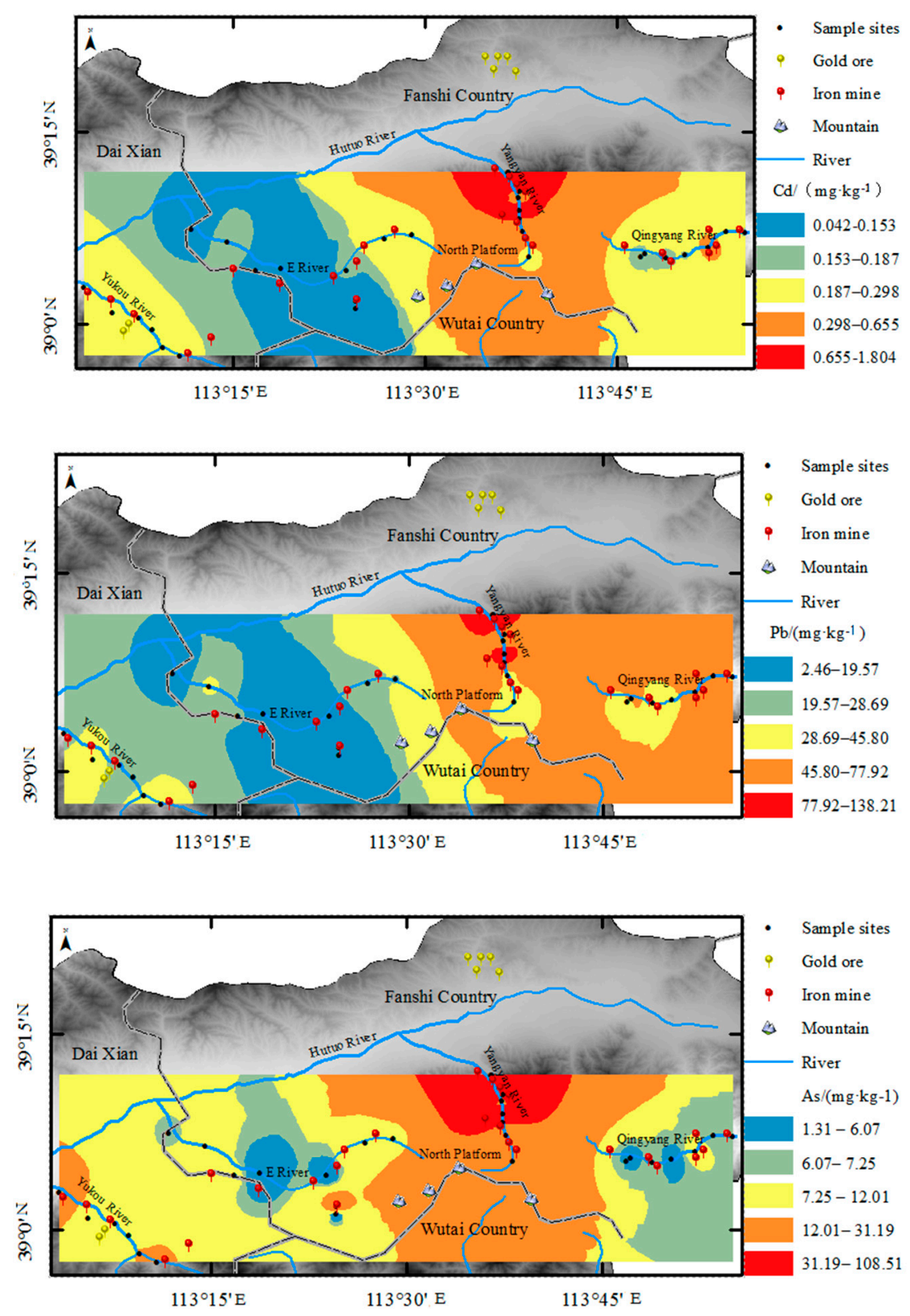

Figure 2. Cont. 


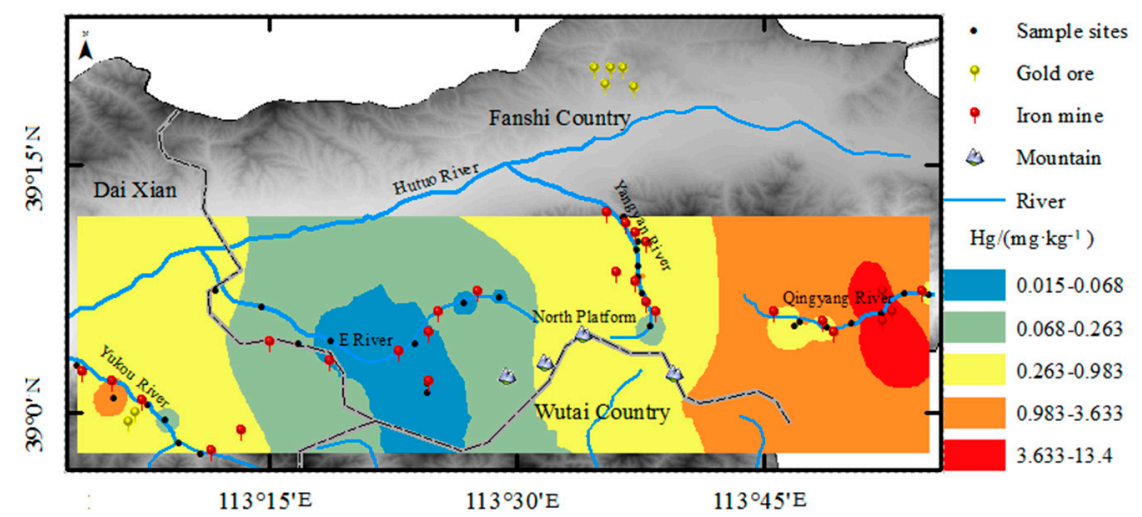

Figure 2. Spatial distribution of heavy metals in agricultural soils of the Mount Wutai area.

\subsection{Evaluation of Heavy Metals Pollution in Agricultural Soils of the Northern Piedmont of Mount Wutai}

Substituting the measured heavy metals data into Equation (1) enabled the SFPI, Pi, to be obtained, and the results are listed in Table 5. The level of Pi heavy metals in the agricultural soils of the Mount Wutai can be ordered as: $\mathrm{Hg}>\mathrm{Cd}>\mathrm{Pb}>$ As. Notably, the level of pollution varied between different watersheds, which mainly reflects the distribution of mines and the scale of mining. There was a slight degree of Cd pollution in the E River; the Yukou River and Qingyang River were moderately polluted; and the Yangyan River was heavily polluted. The degree of $\mathrm{Pb}$ pollution in the Yukou River and $\mathrm{E}$ River was slight, while the Yangyan River and Qingyang River were heavily polluted. The Yukou River was slightly polluted, the E River and Qingyang River were at the alert level, and the Yangyan River was heavily polluted. The levels of $\mathrm{Hg}$ pollution were severe, and the values for the Qingyang River exceed the background by a factor greater than seven, indicating serious pollution.

Table 5. Heavy metals pollution index values for agricultural soils in the northern piedmont mining area of Mount Wutai.

\begin{tabular}{cccccc}
\hline \multirow{2}{*}{ Basin } & \multicolumn{3}{c}{$\mathbf{P i}$} & \multirow{2}{*}{$\mathbf{P}_{\mathbf{N}}$} \\
\cline { 2 - 5 } & $\mathbf{C d}$ & $\mathbf{P b}$ & $\mathbf{A s}$ & $\mathbf{H g}$ & \\
\hline Yukou River & 2.0 & 1.88 & 1.34 & 6.72 & 5.20 \\
E River & 1.40 & 1.07 & 0.72 & 3.51 & 2.75 \\
Yangyan River & 6.52 & 4.45 & 4.29 & 8.93 & 7.63 \\
Qingyang River & 2.17 & 3.18 & 0.75 & 38.82 & 28.58 \\
Mean & 3.02 & 2.65 & 1.78 & 14.50 & 10.96 \\
\hline
\end{tabular}

According to the NIPI, the comprehensive pollution index value was higher by a factor of 10.96 than the highest grading standard, indicating serious pollution levels. Among these values, the Qingyang River basin was as high as 28.58 , which exceeds the grading standard by a factor of 9, indicating severe pollution. The equivalent factors for the Yangyan River and the Yukou River basin were 7.63 and 5.20, respectively, indicating relatively serious heavy metals pollution. The lowest comprehensive pollution index for the E River was 2.75, which indicates moderate pollution.

\subsection{Human Health Risk Assessment}

\subsubsection{Exposure Risk Model}

Based on the parameters of the health risk assessment method and the measured values of the heavy metals, the average daily exposure of adults and children to the four heavy metals could be obtained (Table 6). As shown in Table 6, the average daily exposure of adults to $\mathrm{Cd}, \mathrm{Pb}$, $\mathrm{As}$ and $\mathrm{Hg}$ were $1.86 \times 10^{-7}, 8.00 \times 10^{-5}, 9.31 \times 10^{-6}$, and $1.64 \times 10^{-6} \mathrm{mg} \cdot(\mathrm{kg} \cdot \mathrm{day})^{-1}$, respectively, and the average daily exposures of children were $3.31 \times 10^{-7}, 4.98 \times 10^{-4}, 1.66 \times 10^{-5}$, and $1.16 \times 10^{-5} \mathrm{mg} \cdot(\mathrm{kg} \cdot \mathrm{day})^{-1}$, 
respectively. The average daily exposure of children was higher than that of adults, which is mainly related to the low degree of immunity of children and the greater chance of contact with soil during outdoor activities. The higher degree of daily exposure risk for children than for adults is similar to the results obtained for Yangmin and Chefei $[19,43]$. Compared with adults, the average daily exposure of children to the four heavy metals via the hand-mouth pathway was higher. The average daily exposure of children to $\mathrm{Cd}$ and As via the inhalation pathway was lower than in adults, and for $\mathrm{Pb}$ and $\mathrm{Hg}$ it was higher in children than in adults. Children's daily exposure to heavy metals via skin contact was higher than in adults. Among the different exposure pathways, ingestion was the main route, followed by dermal contact, while heavy metals exposure via inhalation was less harmful to human health.

Table 6. Daily average exposure of the human body to heavy metals in agricultural soils in the northern piedmont of Mount Wutai (mg.(kg.day $\left.)^{-1}\right)$.

\begin{tabular}{cccccc}
\hline Statistic & & $\mathbf{C d}$ & $\mathbf{P b}$ & $\mathbf{A s}$ & $\mathbf{H g}$ \\
\hline \multirow{2}{*}{ ADD $_{\text {ing }}$} & Adult & $1.84 \times 10^{-7}$ & $6.95 \times 10^{-5}$ & $9.28 \times 10^{-6}$ & $1.64 \times 10^{-6}$ \\
\cline { 2 - 5 } & Children & $3.30 \times 10^{-7}$ & $4.97 \times 10^{-4}$ & $1.66 \times 10^{-5}$ & $1.16 \times 10^{-5}$ \\
\hline \multirow{2}{*}{ ADD $_{\text {inh }}$} & Adult & $2.71 \times 10^{-11}$ & $1.02 \times 10^{-8}$ & $1.36 \times 10^{-9}$ & $2.40 \times 10^{-10}$ \\
\cline { 2 - 5 } & Children & $9.27 \times 10^{-12}$ & $1.40 \times 10^{-8}$ & $4.67 \times 10^{-10}$ & $3.29 \times 10^{-10}$ \\
\hline \multirow{2}{*}{ ADD $_{\text {derm }}$} & Adult & $6.64 \times 10^{-10}$ & $2.50 \times 10^{-7}$ & $3.35 \times 10^{-8}$ & $5.89 \times 10^{-9}$ \\
\cline { 2 - 5 } & Children & $8.79 \times 10^{-10}$ & $1.33 \times 10^{-6}$ & $4.43 \times 10^{-8}$ & $3.11 \times 10^{-8}$ \\
\hline \multirow{2}{*}{ ADD } & Adult & $1.86 \times 10^{-7}$ & $8.00 \times 10^{-5}$ & $9.31 \times 10^{-6}$ & $1.64 \times 10^{-6}$ \\
\cline { 2 - 5 } & Children & $3.31 \times 10^{-7}$ & $4.98 \times 10^{-4}$ & $1.66 \times 10^{-5}$ & $1.16 \times 10^{-5}$ \\
\hline
\end{tabular}

\subsubsection{Health Risk Assessment}

The results of the risk assessment are listed in Table 7. For noncarcinogenic risk, $\mathrm{Cd}, \mathrm{Pb}, \mathrm{As}$, and $\mathrm{Hg}$ had values of HQ and HI that were less than 1, indicating there was no health risk. Children have a higher risk of intake than adults via the hand-mouth pathway [44], making HI more important for children than for adults; this is in accord with the results of Li et al. (2008) [45]. The cancer risk of As and Cd exposure indicates higher values of CR and TCR for both adults and children, than the soil standard recommended by the USEPA $\left(10^{-6} / \mathrm{yr}\right)[18,38]$, but lower than the acceptable risk value defined by the USEPA $\left(10^{-6}-10^{-4} / \mathrm{yr}\right)$ [46-48]; however, the carcinogenic risk reached a higher level, which deserves more attention. For children, the carcinogenic risk of As and $\mathrm{Cd}$ was higher than for adults, with TCR indexes of $1.52 \times 10^{-5}$ and $2.70 \times 10^{-5}$, respectively. The individual carcinogenic risk of As exposure is higher than the total carcinogenic risk, with values of $1.39 \times 10^{-5}$ and $2.50 \times 10^{-5}$, respectively; these values were two orders of magnitude lower than the risk indexes for $\mathrm{Cd}$, which are $1.26 \times 10^{-6}$ and $2.01 \times 10^{-6}$, respectively. As appears to be the largest contributor to carcinogenic risk. 
Table 7. Noncarcinogenic risk index and carcinogenic risk in adults and children in the northern piedmont of Mount Wutai.

\begin{tabular}{ccccc}
\hline \multirow{2}{*}{ Element } & \multicolumn{2}{c}{ Hazard Quotient } & \multicolumn{2}{c}{ Carcinogentic Risk } \\
\cline { 2 - 5 } & Adults & Children & Adults & Children \\
\hline $\mathrm{Cd}$ & $1.89 \times 10^{-4}$ & $3.20 \times 10^{-4}$ & $1.26 \times 10^{-6}$ & $2.01 \times 10^{-6}$ \\
$\mathrm{~Pb}$ & $2.04 \times 10^{-2}$ & $1.45 \times 10^{-1}$ & N.A. & N.A. \\
$\mathrm{As}$ & $3.10 \times 10^{-2}$ & $5.52 \times 10^{-2}$ & $1.39 \times 10^{-5}$ & $2.50 \times 10^{-5}$ \\
$\mathrm{Hg}$ & $5.75 \times 10^{-3}$ & $4.00 \times 10^{-2}$ & N.A. & N.A. \\
Hazard Index & $5.73 \times 10^{-2}$ & $2.41 \times 10^{-1}$ & - & - \\
Total Carcinogenic & - & - & $1.52 \times 10^{-5}$ & $2.70 \times 10^{-5}$ \\
Risk & & \multicolumn{4}{c}{} \\
\multicolumn{4}{c}{ N.A.: Pb and Hg are noncarcinogenic heavy metals without SF data. } \\
\hline
\end{tabular}

\section{Discussion and Conclusions}

This study demonstrated that the concentrations of $\mathrm{Cd}, \mathrm{Pb}, \mathrm{As}$, and $\mathrm{Hg}$ in agricultural soils in the Mount Wutai area of Shanxi Province were all higher than the background values; in addition, their spatial distributions were similar. The $\mathrm{pH}$ was an important factor affecting the adsorption of heavy metals. Higher $\mathrm{pH}$ was favorable for adsorption of heavy metals. $\mathrm{Hg}$, which was located around the Qingyang River basin in the eastern part of the study area, exhibited higher values than in other parts of the world, which may be related to the presence of large-scale gold mining activity in the Shahe Town-Dayingkou area in Fanshi County. The method of mixed-mercury extraction results in the release of a large amount of volatile mercury to the atmosphere, and, especially in winter, it accumulates downwind of the gold mining area $[49,50]$ in the Qingyang River basin. The spatial distributions of $\mathrm{Cd}, \mathrm{Pb}$, and As can be summarized as follows: the E River, located in the middle of the country, had the lowest levels, while the Yukou River in the west and the Yangyan River in the east had the highest levels. This distribution is related to the degree of development of iron ore mining, transportation, and the living habits of people in different river basins. The E River is relatively long and the number of mining sites and tailing reservoirs is relatively small. It is relatively less affected by the three main types of waste (waste gases, wastewater, and waste residues). The reaches of the Yukou River, Yangyan River, and Qingyang River, however, are short, and there is a greater degree of industrial and mining activity in the basin. At the mining sites, abandoned slag, derelict machinery, and tailing reservoirs produced as a result of mining are the main causes of heavy metals pollution in the vicinity of mine sites. In the process of adsorption kinetics, the physical and chemical properties and material composition and characteristics all affect the adsorption of heavy metals by soil.

Greater traffic volume in mining areas contributes to high $\mathrm{Pb}$ concentrations [48,51]. High $\mathrm{Cd}$ levels were mainly the result of the accumulation of acidic wastewater and waste discharges from iron ore mining [52-54]. In health risk assessment, the total daily average absorption risk for the four heavy metals indicated that children had a higher health risk than adults. Of the four metals, $\mathrm{Cd}$ had less health risk for children via respiratory intake, mainly because children have a lower respiratory rate; in contrast, As and $\mathrm{Hg}$ posed a greater health risk for adults than children due to their greater body weight and longer duration of absorption. For noncarcinogenic health risks, the levels of the four heavy metals are not significant. For carcinogenic risk, As was the main carcinogenic factor, which may be related to wastewater, waste residue, or tailing pond discharge during iron ore mining; it readily accumulates in agricultural soil via fluvial transportation and wet-dry deposition. In addition, the degree of As pollution is also affected by the living habits of local peoples and by farming practices.

As a result, $\mathrm{Hg}$ was present at the highest levels relative to the background, and this result is consistent with Marin Senila et al. (2012) [55]. Calculation of NIPI values indicated that the northern piedmont is seriously polluted, with the pollution levels of individual river basins in the following order: Qingyang River > Yangyan River $>$ Yukou River $>$ E River. This trend is likely related to the number and scale of iron ore and gold mining activities. The health risk of exposure to heavy metals 
is higher for children than for adults. Hand-mouth intake is the main pathway for heavy metals to enter the human body, followed by skin contact. None of the four heavy metals had a noncarcinogenic health risk. Carcinogenic health risk assessment indicated that As and $\mathrm{Cd}$ present a higher cancer risk and that the cancer risk for children is higher than for adults. The studied agricultural soils were seriously affected by heavy metals pollution, posing a potentially serious hazard to the health of local inhabitants, which should be noted by the relevant administrative bodies. Government departments need to formulate appropriate policies and regulations to reduce risks, and mining activities should be strictly controlled.

Author Contributions: Conceptualization, D.W. and Q.Z.; methodology, D.W., Q.X. and Q.Z.; software, D.W.; validation, Q.Z. and L.W.; formal analysis, D.W.; investigation, D.W. and Q.Z.; resources, Q.Z.; data curation, D.W.; writing-original draft preparation, D.W.; writing-review and editing, D.W., Q.Z. and Q.X.; visualization, D.W. and L.W.; supervision, Q.X. and Q.Z.; project administration, Q.Z.; funding acquisition, Q.X. All authors have read and agreed to the published version of the manuscript.

Funding: This research was funded by [the National Nature Science Foundation of China] grant number [4163000226] and [NSFC-STINT] grant number [41611130050]. The APC was funded by [4163000226].

Acknowledgments: We thank Li Jianxin of the Taiyuan Mineral Resources Supervision and Testing Center Ministry for his help with the laboratory work.

Conflicts of Interest: The authors declare no conflict of interest.

\section{References}

1. Nuremberg, H.W. The voltammetric approach in trace metals chemistry of natural waters and atmospheric precipiation. Anal. Chim. Acta 1984, 164, 1-21. [CrossRef]

2. Nagajyoti, P.C.; Lee, K.D.; Sreekanth, T.V.M. Heavy metals, occurrence and $\mathrm{n}$ toxicity for plants: A review. Environ. Chem. Lett. 2010, 3, 199-216. [CrossRef]

3. Rajczykowski, K.; Loska, K. Stimulation of heavy metals adsorption process by using a strong magnetic field. Water Air Soil Pollut. 2018, 229, 20. [CrossRef]

4. Dong, W.Q.Y.; Cui, Y.; Liu, X. Instances of soil and crop heavy metals contamination in China. Soil Sediment Contam. 2001, 10, 497-510. [CrossRef]

5. Abrabams, P.W. Soils: Their implicantions to human health. The Science of the Total. Environment 2002, 291, $1-32$.

6. Dyer, C.A. Heavy metals as Endocrine-Disrupting chemicals. In Endocrine-Disrupting Chemicals: From Basic Research to Clinical Practice; Gore, A.C., Ed.; Humana Press: Totowa, NJ, USA, 2007; pp. 111-126.

7. Liu, M.S. Harmful element cadmium and human health. Stud. Trace Elem. Health. 2005, 22, 66-67.

8. Żukowska, J.; Biziuk, M. Methodological evaluation of method for dietaryheavy metals intake. J. Food Sci. 2008, 73, R21-R29. [CrossRef] [PubMed]

9. Wei, Y.H.; Huang, Q.C. The toxicological effect of lead on the human health andits measures of preventing. Stud. Trace Elem. Health. 2008, 25, 62-64.

10. Zhang, X.W.; Yang, L.S.; Li, Y.H.; Li, H.R.; Wang, W.Y.; Ye, B.X. Impacts of lead/zinc mining and smeltingon the environment and human health in China. Environ. Monit. Assess. 2012, 184, 2261-2273. [CrossRef] [PubMed]

11. Wu, S.H.; Wang, G.Q.; Liu, K.T. Advances in research on the effects of arsenic on health. Med Geogr. Foreign Ctries. 2002, 23, 145-149.

12. Li, Z.Y.; Ma, Z.W.; Kuijp, T.J.V.D.; Yuan, Z.W.; Huang, L. A review of soil heavy metals pollution from mines in China: Pollution and health risk assessment. Sci. Total. Environ. 2013, 468-469, 843-853. [CrossRef] [PubMed]

13. Li, J.; Yu, T.M.; Zhou, J.; Xie, Z.M. Assessment of health risk for mined soils based on critical thresholds for Lead, Zinc, Cadmium and Copper. Env. Sci. 2008, 29, 2327-2330.

14. Yang, S.X.; Yi, L.B.; Liu, J. Heavy metals concentrations and health risk in vegetables grown on Mn and $\mathrm{Pb} / \mathrm{Zn}$ mineland in Huayuan County, west hunan province, China. J. Agro Environ. Sci. 2012, 31, 17-23.

15. National Environmental Protection Administration of China. Soil Environmental Quality Standard GB15618-1995; Environmental Science Press: Beijing, China, 1995. 
16. Chen, B.; Qiu, H.Y.; Guo, Y.; Wang, L.Y.; Wang, X. Heavy metals contamination and health risk assessment in the zinc mine set area a of Youxi, China. J. Xiamen Univ. (Nat. Sci.) 2012, 51, 245-251.

17. Fang, X.B.; Shi, J.; Liao, X.F.; Lou, Z.; Zhou, L.Y.; Yu, H.X.; Sun, L.P. Heavy metals pollution characteristics and ecological risk analysis for soil in Phyllostachys praecox stands of Lin'an. Chin. J. Appl. Ecol. 2015, 26, 1883-1891.

18. USEPA. Risk Assessment Guidance for SuperfundvolI: Human Health Evaluation Manual; Office of Emergency and Remedial Response; Environmental Protection Agency: Washington, DC, USA, 1989.

19. USEPA. Exposure Factors Handbook; Office of Reserch and Development: Washington, DC, USA, 1997.

20. USEPA. Baseline Human Health risk Assessments. Vasquez Boulevard and 1-70 Superfund Site Denver, Denver(Co); USEPA: Washington, DC, USA, 2001.

21. USEPA. Electronic Code of Federal Regulations, Title 40-Protection of Environment, Part 423d Steam Electric Power Generating Point Source Category. National Archives and Record Administration (NARA, Office of the Federal Register(OFR); USEPA: Washington, DC, USA, 2013.

22. Li, S.X.; Ji, S.K.; Ma, Z.H.; He, G.J.; Tian, Y.Q.; Yang, W.K. Wutaishan Metamorphic Dedimentary Iron Ore Geology; Science and Technology Press: Jilin, China, 1986.

23. Zheng, Q.R. Study on the Evolution Characteristics of Continental Crust in Wutai Mountain and its Adjacent Area; People's Publishing House: Taiyuan, China, 2015.

24. China Environmental Monitoring Center. Modern Analysis Method of Soil Elements; China Environmental Science Press: Beijing, China, 1992.

25. Janarbek, X.; Zhang, L.L.; Teng, E.J.; Liang, X. Application and Progress Inductively Coupled Plasma Mass Spectrometryin soil environmental monitoring. Environ. Chem. 2011, 30, 1799-1804.

26. Song, H.F.; Wu, K.N.; Liu, P.J. Research progress of soil heavy metals pollution assessment methods. Jiangsu Agric. Sci. 2017, 45, 11-14.

27. Ma, D.Y.; Gao, S.; Jin, Z.L.; Zhang, Y.Z.; Zheng, J.W.; Cheng, H.W.S. Study on Soil Environmental Background Value of Wutai Mountain; Environmental Monitoring in China: Hong Kong, China, 1986; Volume 2, pp. $42-44$.

28. Fan, S.X.; Gan, Z.T.; Li, M.J.; Zhang, Z.Q.; Zhou, Q. Progress of assessment methods of heavy pollution in soil. Chin. Agric. Sci. Bull. 2010, 26, 310-315.

29. Nemerow, N.L. Scientific Stream Pollution Analysis; ScriptaBookCo: Washington, DC, USA, 1974.

30. The Ministry of Agriculture of the People's Republic of China. NY/T 395-2012, Technical Specification for Environmental Quality Detection of Agricultural Soil; Standards Press: Beijing, China, 2012.

31. Su-Min, Z.; Rui-Ying, D.; Dian, W.; Chen, Y.; Fu-Hua, W.; Zhao, D.; Zhu, N. Heavy metals pollution in vegetables grown on some agriculturals around Dabaoshan mine and its healthy risk evaluation. J. Agric. Resour. Environ. 2016, 33, 568-575.

32. Li, X.P.; Qi, J.Y.; Chen, Y.H. Preliminary health risk assessment of heavy metals in the main drinking water sources of Guangzhou. Acta Sci. Circumstantiae. 2011, 31, 547-553.

33. Geng, F.M.; Xue, L.Q.; Lu, G.H.; Wu, Y.F. Water quality health-hazard risk assessment on drinking water supply sources. J. Hydraul. Eng. 2006, 37, 1242-1245.

34. Ordonez, A.; Alvarez, R.; Charlsworth, S.; Miguel, E.D.; Loredo, J. Risk assessment of soils contaminated by mercury mining, Northern Spain. J. Environ. Monit. 2011, 13, 128-136. [CrossRef]

35. Chen, X.; Ma, J.H.; Li, X.N.; Liu, D.X.; Li, Y.M. Health risk assessment of soil heavy metals in residential communities built on brownfields. Environ. Sci. 2014, 35, 1068-1074.

36. Wang, Z.S.; Duan, X.L.; Liu, P.; Nie, J.; Huang, N.; Zhang, J.L. Discussion on exposure parameters of Chinese residents in environmental health risk assessment. Environ. Sci. Res. 2009, 22, 1164-1170.

37. Environmental Protection Standards of the People's Republic of China. Technical Guidelines for Risk Assessment of Contaminated Sites (HJ25.3-2014)[R]; The Ministry of Environmental Protection: Beijing, China, 2014.

38. Gu, L.; Tong, Z.Q.; Song, B. Health assessment of heavy metals in roadside soils at different operation time:a case study of Zhengzhou-Shangqiu section along the Lianyungang-Horgas. Highw. Environ. Sci. 2012, 33, 3577-3584.

39. Lim, H.S.; Lee, J.S.; Chon, H.T.; Sager, M. Heavy metals contamination and health risk assessment in the vicinity of the abandoned Songcheon Au-Ag mine in Korea. J. Geochem. Explor. 2008, 96, 223-230. [CrossRef]

40. Health risk assessment on soil heavy metals in the lakeside of East Dongting Lake. Res. Agric. Mod. 2014, 35, 649-653. 
41. Ferreira, B.L.; Miguel, E. Geochemistry and risk assessment of street dust in Luanda, Angola: A tropical urban environment. Atmos. Environ. 2005, 39, 4501-4512. [CrossRef]

42. Yang, Q.; Chen, M.; Hu, L.W. Characteristics and assessment of heavy metals pollution in green space soil of Ganzhou. Chin. J. Soil Sci. 2018, 49, 159-166.

43. Che, F.; Yu, Y.J.; Hu, C. Preliminary health risk assessment of heavy metals in soil in Shen-Fu irrigation area. J. Agro-Environ. Sci. 2009, 28, 1439-1443.

44. Chang, J.; Liu, M.; Li, X. Primary research on health risk assessment of heavy metals in road dust of Shanghai. China Environ. Sci. 2009, 29, 548-554.

45. Li, Y.Y.; Xiong, G.Z. The toxicity mechanism and clinical research progress of mercury poisoning. Chinese J. Emerg. Recovery Disaster Med. 2008, 3, 57-59.

46. Chen, H.; Teng, Y.; Lu, S.; Wang, Y.; Wang, J. Contamination features and health risk of soil heavy metals in China. Sci. Total. Environ. 2015, 512-513, 143-153. [CrossRef]

47. Zhang, X.; Zhong, T.; Liu, L.; Ouyang, X. Impact of soil heavy metals pollution on food safety in China. PLoS ONE 2015, 10, e0135182. [CrossRef]

48. Chen, J.X.; Sun, Y.Y.; Liu, X.; Li, Y.J.; Li, Y.L. Assessment on the health risk of soil heavy metals in two non-ferrous metals exploration areas in eastern Inner Mongolia. J. Arid. Land Resour. Environ. 2018, 32, 140-146.

49. Garcia-Sanchez, A.; Murciego, A.; Alvarez-Ayusoa, E.; Santa Regina, I.; Rodriguez-Gonzalez, M.A. Mercury in soils and plants in an abandoned cinnabar mining area (SWSpain). J. Hazard. Mater. 2009, 168, 1319-1324. [CrossRef]

50. Gosar, M.; Pirc, S.; Sajn, R.; Bidovec, M.; N. Mashyanov, S. SholupovDistribution of mercury in the atmosphere over Idrija, Slovenia. Environ. Geochem. Health 1997, 19, 101-110. [CrossRef]

51. Wu, Y.; Hu, Y.; Ma, Y.; Wu, J.; Lian, Y.; Shen, Q. Research advances in influence of highway traffic on lead pollution in soil. Acta Agric. Jiangxi 2013, 25, 75-78.

52. Gray, C.W.; McLaren, R.G.; Roberts, A.H.C.; Condron, L.M. The effect of long-term phosphatic fertiliser applications on the amounts and forms ofcadmium in soilsunder pasture in NewZealand. Nutr. Cycl. Agro eco Syst. 1999, 54, 267-277. [CrossRef]

53. Liu, Q.; Wang, J.; Shi, Y.X.; Zhang, Y.Y.; Wang, Q.H. Heavy metals pollution in cropland soil in cixi city of Zhejiang Province. J. Agro Environ. Sci. 2007, 26, 639-644.

54. Rodrigues, S.; Pereira, M.E.; Duarte, A.C.; Ajmone-Marsan, F.; Davidson, C.M.; Grčman, H.; Hossack, I.; Hursthouse, A.S.; Ljung, K.; Martini, C.; et al. Mercury in urban soils: Acomparison of localspatial variability in six European cities. Sci. Total. Environ. 2006, 368, 926-936. [CrossRef] [PubMed]

55. Marin senila, M.; Levei, E.A.; Senila, L.R.; Oprea, G.M.; Roman, C.M. Mercury in soil and perennial plants in a mining-affected urban area from Northwestern Romania. J. Environ. Sci. Health. Pt. A 2012, 47, 614-621. [CrossRef] [PubMed]

(C) 2020 by the authors. Licensee MDPI, Basel, Switzerland. This article is an open access article distributed under the terms and conditions of the Creative Commons Attribution (CC BY) license (http://creativecommons.org/licenses/by/4.0/). 